\title{
Kebijakan, Risiko, dan Perlindungan Sosial Alternatif dalam Transisi Pemuda di Jawa Tengah
}

\section{Muhammad Rosyid Budiman, Farid Ali Syahbana, Yanti Nurhasanah, Derajad S. Widhyharto, Aditya R. Pratama}

\author{
Universitas Gadjah Mada
}

rosyidbudiman@gmail.com | alisyahbanaf@gmail.com | yantinurhasanah03@gmail.com derajad@gmail.com | aditya.rizki.p@mail.ugm.ac.id

\begin{abstract}
ABSTRAK
Jawa Tengah merupakan provinsi dengan persentase penduduk miskin terbesar di Pulau Jawa. Tingginya angka kemiskinan disebabkan berbagai faktor yang saling terkait seperti birokrasi dan pemerintahan, ketersediaan infrastruktur, serta akses pendidikan dan informasi. Salah satu masalah terpenting terkait birokrasi dan pemerintahan di Indonesia adalah mengenai belum optimalnya pelaksanaan perlindungan sosial. Studi ini menggunakan metode kualitatif untuk menganalisa pemuda rentan (miskin dan difabel) di Jawa Tengah dengan mengetahui bagaimana mereka melalui transisi menuju dunia kerja tanpa sistem perlindungan sosial yang memadai. Tanpa perlindungan sosial yang memadai pemuda dihadapkan pada risiko-risiko tanpa proteksi dari negara. Permasalahan terkait ketersediaan pendidikan, jaminan kesehatan, dan ketersediaan lapangan kerja adalah beberapa isu strategis yang menjadi perhatian. Dengan peran pemerintah yang belum optimal, pemuda diharuskan mencari alternatif untuk melindungi diri dari risiko-risiko seperti putus sekolah, pengangguran, dan kemiskinan yang berkelanjutan. Pemuda rentan di Jawa Tengah mengambil pilihan-pilihan yang berbeda sesuai dengan tantangan yang dihadapi dan pilihan yang tersedia. Terdapat perbedaan pilihan yang diambil oleh pemuda daerah pinggir (periphery) seperti Jawa Tengah dengan pemuda dari daerah pusat seperti Jakarta. Perbedaan akses terutama pada infrastruktur fisik dan akses informasi menjadi salah satu pembeda utama pilihan-pilihan yang dimiliki dan diambil oleh pemuda rentan dalam mencari alternatif substitusi perlindungan sosial formal dari pemerintah.
\end{abstract} KATA KUNCI Pemuda | Kebijakan | Perlindungan Sosial | Desa-Kota

\section{PENDAHULUAN}

Pemuda dalam perspektif youth transition dipandang sebagai proses transisi menuju dewasa dengan tiga domain utama yakni pendidikan, pekerjaan, dan pernikahan. Seseorang dianggap dewasa ketika sudah menyelesaikan pendidikan dan bekerja, menikah, dan tinggal di rumah sendiri terpisah dari rumah orang tua (Wyn dan Whyte 1997; Minza 2014). Pada perkembangannya, transisi yang dialami pemuda pada era modern akhir (late modernity) mengalami pergeseran seiring perubahan kondisi sosial, ekonomi dan politik (France 2007). Masa transisi menjadi masa penuh ketidakpastian bagi pemuda sehingga diibaratkan suatu perjalanan yang berliku (zig-zag journey) (Sutopo 2014).
Selain dipandang sebagai masa transisi, pemuda juga dikaitkan dengan risiko. Dalam konteks Indonesia, risiko yang dianggap terkait pemuda adalah kenakalan remaja, perilaku seks bebas, penyalahgunaan narkoba dan obat terlarang, dan kekerasan. Padahal dalam transisi pemuda terdapat risiko-risiko yang lebih besar. Hal ini bisa dilihat pada bagaimana transisi pemuda pada era modern akhir dilihat sebagai zig-zag journey yang menggambarkan ketidakpastian. Perubahan lanskap sosial, politik, dan ekonomi berimplikasi pada perubahan risiko yang dihadapi pemuda dalam bertransisi memasuki dunia kerja. Dalam konteks Indonesia, hal ini dapat dilihat misalnya dari bagaimana pemuda pasca-krisis ekonomi 
1998 harus refleksif terhadap perubahan rules of the game di dunia kerja, dan sekaligus harus berhadapan dengan berlapis-lapis hambatan struktural lain (Sutopo dan Meiji 2017).

Proses transisi pada tiga domain yang semula merupakan keniscayaan, perlahan bergeser menjadi proses yang tidak pasti. Makin mahalnya biaya pendidikan mendorong pemuda untuk langsung masuk dunia kerja atau bekerja sebelum menempuh pendidikan tinggi. Sebaliknya, pemuda yang menyelesaikan pendidikan tinggi melanjutkan sekolah karena pekerjaan yang ada tidak sesuai dengan profil pendidikannya. Dari kondisi di atas dapat dilihat bahwa satu risiko bisa membawa pada risiko lain. Pemuda yang memutuskan untuk bekerja tanpa menempuh pendidikan tinggi umumnya mendapatkan pekerjaan dengan penghasilan yang rendah. Sedangkan mereka yang meneruskan sekolah dibebani biaya pendidikan yang semakin mahal dan ketidakpastian untuk mendapatkan pekerjaan yang sesuai dengan profil pendidikannya.

Risiko yang dihadapi pemuda dipengaruhi berbagai aspek, di antaranya adalah kewarganegaraan (nationality) dan kelas sosial. Dalam konteks ini muncul istilah Global North yang mengacu pada warga dari negara yang menerapkan sistem welfare state, dan masyarakat kelas sosial atas di negara bukan welfare state. Sebaliknya, istilah Global South selain mengacu pada warga dari negara yang tidak menerapkan sistem welfare state, juga mengacu pada kelas sosial bawah di negara bersistem welfare state (Minza 2014). Dalam konteks Global South, yang memiliki tantangan terbesar dalam menghadapi risiko-risiko dalam proses transisi adalah pemuda miskin dan pemuda difabel. Difabel memiliki risiko tambahan seperti lingkungan (termasuk kemiskinan), stigma dan diskriminasi, interaksi yang buruk dengan orang tua dan pendamping (caregivers), kekerasan, perundungan dan penelantaran, serta keterbatasan akses pada program dan layanan. Menurut World Health Organization (WHO) risiko tambahan yang dihadapi difabel muncul dikarenakan kondisi fisik, sosial, dan perlakuan yang diterima dari lingkungan tempat tinggal terutama bagi mereka yang tinggal diluar wilayah pusat (Killing et al. 2018). Sebagaimana disampaikan di atas, dalam konteks Global North maka "pusat" bisa dilihat sebagai negara-negara welfare state atau kelas sosial atas meski bukan warga negara welfare state. Dalam konteks geografis di Indonesia, menurut penulis, "pusat" secara sederhana dapat terwakili oleh kota-kota besar (urban) terutama Jakarta sebagai ibukota negara dan "pinggiran" dapat terwakili oleh kota-kota kecil dan wilayah pedesaan (rural). Studi ini bertujuan untuk mendalami lebih lanjut bagaimana transisi pemuda rentan di Jawa Tengah memasuki dunia kerja ditengah perlindungan sosial yang kurang memadai. Studi ini juga membandingkan variasi perlindungan sosial alternatif yang diupayakan pemuda di Jawa Tengah yang merupakan daerah "pinggiran" dengan pemuda di Jakarta yang merupakan wilayah urban sekaligus merupakan wilayah "pusat" dalam konteks Indonesia.

\section{STUDI TERDAHULU}

Beberapa studi terkait membantu memberikan gambaran tentang kondisi ketenagakerjaan, kemiskinan dan difabilitas di Jawa Tengah menjadi landasan awal studi ini. Wahyudi dan Rejekingsing (2013) misalnya, melakukan penelitian untuk menganalisa kemiskinan di Jawa Tengah, dimana lebih dari 50\% penduduk miskin Pulau Jawa terpusat, dengan $20,02 \%$ di antaranya berada pada taraf miskin absolut. Studi tersebut menemukan bahwa 50\% kabupaten/kota di Jawa Tengah memiliki tingkat kemiskinan absolut lebih dari 20\%. Dari beberapa faktor yang mempengaruhi tingkat kemiskinan di Jawa Tengah, salah satunya adalah pengeluaran pemerintah, semakin besar pengeluaran pemerintah di suatu daerah, semakin kecil angka kemiskinan yang ada.

Studi lain oleh Kertati (2013) menganalisa kemiskinan Kota Semarang berdasar data Pendataan Program Perlindungan Sosial (PPLS). Studi ini menemukan banyak penduduk mengalami permasalahan pendidikan, pekerjaan, dan kesehatan. Studi ini menganalisa program pengentasan kemiskinan pemerintah yang melibatkan stakeholder terkait. Kertati menyimpulkan masalah kemiskinan yang jamak ditemukan terkait dengan pendidikan, kesehatan, infrastruktur, dan ketenagakerjaan. Salah satu temuan terkait peran pemerintah dalam penanggulangan kemiskinan adalah rendahnya dana yang dikeluarkan, selain itu ada temuan bahwa pendanaan APBD 
kurang menyasar langsung pada masyarakat miskin sehingga program dan kegiatan belum berhasil.

Terkait difabilitas dan kemiskinan, Abdi dan Sharma (2014) mengatakan permasalahan difabilitas, kemiskinan, dan pengangguran berakar dari berbagai faktor seperti stigma sosial, stereotyping, kurangnya akses infrastruktur fisik dan informasi, serta lingkungan yang belum mendukung. Salah satu faktor terpenting untuk melakukan perubahan adalah political will dari penyusun dan peraturan dan perundang-undangan. Permasalahan lain adalah terfokusnya gerakan-gerakan pro-difabilitas pada peningkatan pelayanan pada penyandang difabilitas namun kurang mendorong usaha advokasi pada isu terkait dengan kebijakan yang lebih pro-difabilitas. Studi ini bertujuan menggali lebih dalam mengenai pelaksanaan kebijakan terkait upaya mendorong terwujudnya ketenagakerjaan inklusif di Indonesia. Secara spesifik studi ini mengeksplorasi hambatan pelaksanaan kebijakan yang muncul dalam birokrasi pemerintahan dan juga dalam relasi antara pemerintah dengan stakeholder lain. Studi ini juga mengeksplorasi pengalaman yang dialami pemuda dalam kaitannya dengan proses untuk masuk ke dunia kerja di Jawa Tengah.

\section{METODE PENELITIAN}

Studi ini menggunakan pendekatan kualitatif untuk mendapatkan gambaran yang tepat tentang permasalahan yang dihadapi pemuda rentan di Jawa Tengah dalam transisi menuju dunia pekerjaan. Pendekatan kualitatif dianggap tepat untuk menganalisa fenomena sosial dengan menekankan pada kualitas, substansi, dan pengalaman manusianya (Marvasti 2003). Studi ini berfokus pada dua wilayah di Jawa Tengah, yakni Kabupaten Semarang dan Kabupaten Boyolali. Pengumpulan data dilakukan dengan Focus Group Discussion (FGD) dan wawancara mendalam (in-depth interview), lebih lanjut dilakukan observasi atas situasi lingkungan tinggal informan untuk mendapatkan informasi-informasi yang tersirat sebagai pelengkap apa yang disampaikan secara literal oleh informan.

Informan dalam studi ini adalah pihak-pihak terkait dengan isu angkatan kerja di Jawa Tengah, di antaranya adalah pemerintah diwakili beberapa dinas tingkat kabupaten (Badan Perencanaan Pembangunan Daerah (Bappeda), Dinas Tenaga Kerja (Disnaker), Dinas Sosial (Dinsos), Balai Latihan Kerja (BLK)), perwakilan pemuda rentan (miskin dan difabel), perwakilan perusahaan, perwakilan organisasi pemuda, perwakilan organisasi difabel dan Masyarakat Madani / Civil Society Organization (CSO). Selain perwakilan dalam FGD, wawancara juga dilakukan pada informan (pemuda rentan) dengan pemilihan informan menggunakan teknik purposive sampling. Pemilihan informan dilakukan dengan mempertimbangkan keterwakilan pemuda miskin, pemuda difabel, gender, dan wilayah tinggal untuk mendapatkan gambaran yang utuh dari berbagai latar belakang yang berbeda.

\section{KONDISI UMUM KEBIJAKAN PERLIND- UNGAN SOSIAL DI INDONESIA}

Perlindungan Sosial merupakan salah satu isu penting dalam menjamin keberlangsungan hidup masyarakat dari risiko kemiskinan, pengangguran, hingga disabilitas. Bagi kaum muda, perlindungan sosial merupakan salah satu kebutuhan primer, tidak hanya warga negara tetapi juga terhadap perannya sebagai sumber daya manusia dan generasi penerus yang akan menjadi penggerak dalam sektor ekonomi, politik hingga sosial dan budaya. Penjaminan kesejahteraan dan keamanan sosial bagi kaum muda adalah faktor penting dalam menjaga korelasi yang baik antara ketersediaan sumber daya manusia, keberlangsungan hidup, maupun produktivitasnya pada kemajuan berbagai sektor kehidupan yang bermuara pada tercapainya visi besar pembangunan berkelanjutan.

Menurut Organisasi Perserikatan Bangsa-Bangsa (PBB) (2012) dalam Laporan United Nations System Task Team on the Post-2015 UN Development Agenda, perlindungan sosial adalah suatu upaya atau program yang disusun oleh pemerintah maupun swasta dalam menangani berbagai dimensi kemiskinan dan ketidakberdayaan (meliputi; pekerjaan yang layak, pendidikan, perawatan kesehatan, keamanan pangan, dan keamanan pendapatan) sebagai alat dalam menghadapi permasalahan kemiskinan dan ketidaksetaraan. Perlindungan sosial dalam 
hal ini diharapkan dapat memberikan perlindungan bagi masyarakat terhadap ancaman-ancaman sosial utamanya yang timbul akibat 4 faktor; siklus hidup (life-cycle), ekonomi, lingkungan, dan sosial pemerintahan (Norton, Conway dan Foster 2001):

a. Lifecycle: Misalnya cacat, kematian, dan lanjut usia.

b. Economic: Misalnya kegagalan panen, penyakit hama, pengangguran, peningkatan harga kebutuhan dasar, dan krisis ekonomi

c. Environmental: Misalnya kekeringan, banjir, dan gempa bumi.

d. Social/governance: Misalnya kriminalitas, ke kerasan domestik, dan ketidakstabilan politik.

Terdapat banyak pendapat dan kajian ilmu sosial dalam menafsirkan dan memetakan penjabaran definisi dari perlindungan sosial itu sendiri. Secara garis besar perlindungan sosial dapat dimaknai sebagai upaya penanggulangan kemiskinan dan ancaman keamanan ekonomi maupun sosial bagi masyarakat. Oleh lembaga Internasional United Nations Human Rights, perlindungan sosial mengacu pada kebijakan dan program yang bertujuan memungkinkan orang untuk merespons berbagai kemungkinan dan mengelola tingkat risiko atau kekurangan terhadap hal-hal yang dianggap tidak dapat diterima oleh masyarakat (Carmona dan De Schutter 2012).

United Nations High Commissioner for Refugees mendefinisikan perlindungan sosial mengacu pada seperangkat kebijakan dan/atau program yang bertujuan untuk melindungi setiap orang dari ancaman kemiskinan, kerentanan, dan social exclusion (keterasingan sosial) sepanjang siklus hidupnya dengan penekanan khusus pada bantuan untuk bertahan hidup, berkembang dan menjadi tangguh dalam ketika menghadapi risiko tekanan perubahan atau bencana (United Nations 2018).

Di Indonesia, perlindungan sosial diatur melalui Undang-Undang No. 11 Tahun 2009 tentang Kesejahteraan Sosial, dimana perlindungan sosial didefinisikan sebagai "Semua upaya yang diarahkan untuk mencegah dan menangani risiko dari guncangan dan kerentanan sosial seseorang, keluarga, kelompok, dan/atau masyarakat agar kelangsungan hidupnya dapat dipenuhi sesuai dengan kebutuhan dasar minimal." Regulasi ini mengatur tanggung jawab negara dalam perlindungan sosial warga negaranya setidaknya dapat melalui tiga penyelesaian konkret: bantuan sosial, advokasi sosial, dan bantuan hukum. Secara lebih detail, Undang-Undang No. 11 Tahun 2009 menjelaskan bahwa:

\section{1) Bantuan Sosial}

a. Bantuan sosial dimaksudkan agar seseorang, keluarga, kelompok, dan/atau masyarakat yang mengalami guncangan dan kerentanan sosial dapat tetap hidup secara wajar.

b. Bantuan sosial sebagaimana dimaksud bersifat sementara dan/atau berkelanjutan dalam bentuk: bantuan langsung; penyediaan aksesibilitas; dan/ atau penguatan kelembagaan.

\section{2) Advokasi Sosial}

a. Advokasi sosial dimaksudkan untuk melindungi dan membela seseorang, keluarga, kelompok, dan/ atau masyarakat yang dilanggar haknya.

b. Advokasi sosial sebagaimana dimaksud diberikan dalam bentuk penyadaran hak dan kewajiban, pembelaan, dan pemenuhan hak.

\section{3) Bantuan Hukum}

a. Bantuan hukum diselenggarakan untuk mewakili kepentingan warga negara yang menghadapi masalah hukum dalam pembelaan atas hak, baik di dalam maupun di luar pengadilan.

b. Bantuan hukum sebagaimana dimaksud diberikan dalam bentuk pembelaan dan konsultasi hukum.

Dalam Rencana Pembangunan Nasional tahun 2015-2019, perlindungan sosial dimaknai sebagai serangkaian kebijakan pemerintah yang berfokus pada penyelesaian permasalahan kemiskinan dan kesenjangan pembangunan melalui pertumbuhan ekonomi inklusif, investasi padat pekerja, serta perhatian khusus terhadap usaha mikro, perlindungan sosial serta berbagai layanan masyarakat berupa jaminan sosial dan pemenuhan hak dan kebutuhan dasar bagi warga negara khususnya yang dikategorikan sebagai penduduk miskin dan pedesaan. 
Menurut Amiluddin (2016) beberapa manfaat dari perlindungan sosial, di antaranya:

1. Terlindunginya manusia dari berbagai risiko sehingga terhindar dari kesengsaraan yang berkepanjangan.

2. Meningkatnya kemampuan kelompok rentan dalam menghadapi kemiskinan serta keluarnya dari kemiskinan dimaksud.

3. Keluarga miskin memiliki standar hidup bermatabat

4. Tercapainya dan terselenggaranya kesejahteraan sosial.

Perlindungan sosial memberikan akses pemenuhan kebutuhan dasar dan hak-hak dasar manusia, termasuk akses pada pendapatan, kehidupan, pekerjaan, kesehatan, pendidikan, gizi, dan tempat tinggal. Selain itu perlindungan sosial juga dimaksudkan untuk menanggulangi kemiskinan dan kerentanan absolut yang dihadapi oleh penduduk yang sangat miskin.

\section{Perlindungan Sosial bagi Kaum Muda}

Dinamika dunia kerja erat kaitannya dengan pemuda. Hal ini mengacu pada rentang usia pemuda yaitu 16-30 tahun, masa dimana individu pada umumnya memasuki kematangan fisik maupun mental sehingga mendorong daya kreativitas dan produktivitasnya secara optimal. Indonesia memiliki 63,82 juta jiwa pemuda, di mana kelompok pemuda bekerja mencapai $52,87 \%$ populasi atau setara dengan 33,7 juta jiwa (Badan Pusat Statistik 2018).

Dengan potensi perkembangan kreasi dan inovasi oleh pekerja muda, lapangan kerja menjadi wadah pemuda untuk menuangkan ide maupun tenaga untuk produktif berkarya. Dengan kondisi yang minim akan sumber daya kapital dalam berbisnis dan mengembangkan kondisi finansial, kesempatan kerja menjadi peluang bagi pemuda untuk menyalurkan produktivitas, mengembangkan diri, dan menjamin kesejahteraannya secara mandiri. Pesatnya perkembangan teknologi membawa perubahan positif pada dunia kerja. Pilihan pekerjaan yang lebih banyak dan beragam menarik pemuda untuk memasuki dunia kerja dengan berbagai pilihan. Di sisi lain, perkembangan kompetisi pasar, industri dan perdagangan, serta fenomena bonus demografi menjadikan posisi pemuda sebagai sumber tenaga kerja sebagai hal yang penting bagi sektor industri.

Dibalik kesempatan kerja yang diperoleh, pemuda di dunia kerja menghadapi persoalan serius terkait perlindungan sosial sebagai pekerja. Perlindungan sosial harus menjadi hak bagi semua pekerja termasuk informal yang turut berkontribusi terhadap ekonomi secara keseluruhan. Mereka harus memiliki hak yang sama dengan pekerja formal atas perlindungan sosial, dan kondisi kerja yang sehat dan aman. Di Indonesia jumlah pekerja di sektor informal mencapai 41,93\%, tidak berbeda jauh dengan 58,01\% pekerja muda di sektor formal (Badan Pusat Statistik 2018). Sebagian besar pekerja informal terjebak dalam kondisi kemiskinan. Secara konsisten, mereka sendiri mendaftar akses ke layanan kesehatan, perawatan anak, dan pensiun ketika mereka semakin tua sebagai prioritas tinggi dalam perlindungan sosial (Women in Informal Employment: Globalizing and Organizing (WIEGO) 2018).

Perlindungan sosial dan pemenuhan hak dasar bagi pekerja merupakan tanggung jawab pemerintah sebagai penyelenggara negara yang diberi amanah untuk menjamin kesejahteraan sosial bagi seluruh rakyat Indonesia sebagaimana tertuang $\mathrm{da}-$ lam Pembukaan Undang-Undang Dasar 1945. Di samping menjamin kesejahteraan sosial, progresivitas yang terproyeksi dari tingkat kesejahteraan masyarakat bisa menjadi tolok ukur keberhasilan program pembangunan pemerintah.

Tidak dapat dipungkiri, program perlindungan sosial adalah unsur pokok yang sangat berpengaruh untuk memerangi kemiskinan dan menekan penderitaan multidimensi yang dialami oleh kelompok miskin dan rentan. Pemenuhan atas hak-hak dasar rakyat termasuk bebas dari kemiskinan, pengangguran, keterbelakangan, ketidakadilan, penindasan, rasa takut, dan kebebasan mengemukakan pikiran serta pendapatnya perlu dijadikan prioritas. Pembangunan harus mampu membebaskan rakyat dari berbagai belenggu yang menghambat ruang gerak dalam mengekspresikan dan mewujudkan nilainilai dan tujuan bersama. Pemuda yang diandalkan sebagai generasi penerus masih menjadi tanggungan negara dalam hal pemenuhan hak-hak dasar, termasuk 
dalam hal memperoleh pekerjaan yang layak, perlindungan hukum, hak akses terhadap kebutuhan hidup baik sandang, pangan, papan, pendidikan, kesehatan, beragama atau memeluk kepercayaannya, dan hak untuk terlibat dalam aktivitas politik (Strategic Alliance for Poverty Alleviation 2018).

Kebijakan formal atau program perlindungan sosial pemerintah dalam konteks di negara-negara Asia Tenggara termasuk Indonesia dapat dikategorikan dalam lima komponen, antara lain: kebijakan pasar kerja, kebijakan bantuan sosial, asuransi sosial, skema berbasis masyarakat, dan kebijakan terkait dengan perlidungan anak (Suharto 2009). Selain kebijakan publik yang formal, definisi perlindungan sosial juga mencakup praktik-praktik informal seperti arisan, sistem gotong-royong dalam masyarakat, dukungan keluarga atau teman-teman serta skema-skema jaring pengaman sosial yang berbasis masyarakat.

Sifat dasar manusia sebagai makhluk sosial tidak dapat meninggalkan kebutuhannya untuk berinteraksi dan bersosialisasi. Dengan membentuk komunitas dan berjejaring setiap warga negara dapat memperluas aksesnya dalam memeroleh perlindungan sosial yang tidak selalu berasal dari program pemerintah. Suatu organisasi kepemudaan atau perkumpulan mahasiswa berdasarkan hobi dapat membangun jejaring sosial yang membuka akses-akses perlindungan sosial. Permasalahan sosial seperti kemiskinan tidak hanya dapat diatasi dengan bantuan subsidi bahan bakar atau bantuan langsung tunai, tetapi bahkan dapat terpenuhi dengan kegiatan pendanaan bersama (crowd funding) atau melalui program berbasis kreativitas lainnya. Dalam penjaminan keamanan finansial dan kesejahteraaan pun demikian, persoalan pengangguran tidak lagi harus teratasi melalui program pemerintah job fair atau pelatihan-pelatihan kerja di Balai Latihan Kerja. Namun hal ini dapat diakses melalui forum-forum komunitas anak muda berbasis kesamaan minat atau hobi yang lebih informal.

Di tengah perkembangan teknologi dan informasi yang pesat, kebutuhan untuk bersosialisasi dan berinteraksi semakin terbuka dengan banyaknya platform komunikasi interaktif antar individu dengan medium yang semakin kaya mulai dari tulisan, suara, gambar, dan audio-visual. Perkembangan teknologi mempermudah komunikasi dan terhubungnya masyarakat termasuk pemuda ke dalam komunitas-komunitas sosial berbasis digital. Dengan inovasi-inovasi yang dilahirkan oleh para penyedia jasa informasi dan platform media sosial saat ini, generasi muda dapat membangun konektivitas dan komunikasi tanpa terkendala batas wilayah. Permasalahan sosial yang muncul semakin mudah terpublikasi dan diakses oleh masyarakat luas, sehingga semakin cepat pula penyelesaiannya. Kita dapat melihat bagaimana penyelesaian bencana kelaparan yang melanda Suku Asmat di Papua beberapa waktu lalu mendapat perhatian besar dengan bantuan mencapai 241 Miliar Rupiah hanya melalui media sosial (Taqwa 2018). Selain itu, berita tentang bencana tsunami yang baru saja terjadi di Palu, Sigi dan Donggala yang secara cepat tersebar ke berbagai penjuru daerah bahkan berbagai belahan negara di dunia, setidaknya tercatat 29 negara telah mengirimkan bantuan internasional untuk korban bencana yang terus berdatangan (BBC. 2018).

Begitu pula bagi pemuda urban yang hidup di tengah peradaban modern. Akses informasi lapangan pekerjaan tidak lagi terbatas pada papan informasi di kantor kecamatan atau dari saudara yang bekerja di suatu perusahaan. Dengan media sosial atau jejaring pencari kerja berbasis sosial media di internet berbagai informasi lapangan pekerjaan dapat diakses dengan mudah. Bukan hal aneh ketika prosedur rekrutmen pekerjaan konvensional seperti seleksi administrasi atau wawancara diselenggarakan dengan cara-cara berbasis digital. Selain itu, jumlah dan jenis pekerjaan semakin banyak dan beragam hingga pekerjaan-pekerjaan baru tercipta berkat kemajuan perkembangan teknologi dan semakin kuatnya konektivitas yang menghubungkan masyarakat. Semakin berkembangnya perusahaan-perusahaan startup, e-commerce, financial technology, online shop, dan berbagai platform digital lainnya membanjiri pasar dan membuka lapangan pekerjaan baru. Memasuki zaman revolusi industri 4.0 ini, kehidupan masyarakat modern membangun konektivitas yang jauh lebih luas dan intensif dari sebelumnya dan membuka peluang media perlindungan sosial baru bagi masyarakat, khususnya kaum muda urban tanpa 
sepenuhnya mengandalkan program-program kebijakan pemerintah.

Permasalahan dalam Pelaksanaan Perlindungan Sosial di Jawa Tengah

Salah satu permasalahan kepemudaan di Indonesia adalah ketersediaan lapangan kerja. Data BPS (2016) menunjukkan tingkat pengangguran pemuda (usia 15-29 tahun) mencapai 31\% di perkotaan dan $25 \%$ di perdesaan. Dalam kondisi ideal, permasalahan kesejahteraan warga negara menjadi tanggung jawab pemerintah. Di Indonesia kebijakan ke arah itu sudah mulai tampak, hal ini bisa dilihat dari mulai adanya jaminan sekolah gratis hingga jenjang menengah atas dan dibentuknya Badan Penyelenggara Jaminan Sosial (BPJS). Terkait isu difabel, UU No. 8 Tahun 2016 dalam pasal 53 mengharuskan adanya alokasi khusus posisi pekerjaan bagi difabel, di entitas pemerintah sebesar $2 \%$ dan di entitas swasta setidaknya $1 \%$ dari jumlah pekerja yang ada. Pada pelaksanaannya, hal tersebut belum bisa diwujudkan. Hak-hak difabel diakui melalui UU No.8 Tahun 2016 yang meliputi hak hidup; hak bebas dari stigma; hak privasi, keadilan dan perlindungan hukum; hak pendidikan; hak pekerjaan, kewirausahaan dan koperasi; dan hak kesehatan. Dalam implementasinya masih banyak hambatan bagi pemuda difabel untuk mendapatkan kondisi yang setara dengan non-difabel. Terdapat setidaknya tiga faktor yang memiliki pengaruh besar dalam proses transisi pemuda rentan memasuki dunia kerja yakni kordinasi antar-pelaksana kebijakan, akses, dan persepsi atas pemuda rentan. Dari ketiga faktor tersebut faktor kordinasi dan akses akan ditinjau lebih lanjut untuk melihat bagaimana kondisi yang dihadapi pemuda rentan dalam transisi memasuki dunia kerja.

Melihat Jawa Tengah, salah satu permasalahan adalah faktor kordinasi antar-pelaksana kebijakan dimana stakeholder yang memiliki kekuatan untuk mewujudkan kondisi ideal tersebut belum bersinergi dengan baik. Di antara pihak-pihak ini adalah pemerintah, perusahaan, serta Lembaga Swadaya Masarakat (LSM), dan Masyarakat Madani (Civil Society Organization/CSO). Permasalahan kordinasi antar-stakeholder merupakan salah satu permasalahan pokok mengingat fungsi pelaksana dan kontrol kebijakan terletak disini. Permasalahan ini terungkap dalam FGD dan berupa permasalahan klasik birokrasi seperti ketidakakuratan data, ego sektoral antar-dinas, kebijakan dengan pendekatan top down, dan permasalahan anggaran masih menjadi hambatan utama.

Ketiadaan data yang akurat menjadi salah satu permasalahan yang pertama kali muncul dalam FGD. Keterangan peserta memberikan gambaran terkait pemasalahan data ini sebagai berikut:

\footnotetext{
"Tidak ada satu data pun yang bisa kita percaya saat ini. BDT 2015 dengan segala kelebihan dan kekurangan saat itu. Orang miskin yang ada dalam BDT itu tidak semua betul.”. (Anang, Kepala Bappeda Kab. Semarang, 2018)
}

Persoalan terkait kerjasama dan kordinasi antar-dinas pemerintah juga muncul dalam FGD, sebagian merupakan efek dari aturan formal, sebagian lain dikarenakan dinamika kedinasan yang timbul dari perubahan nomenklatur. Seperti yang dijelaskan di oleh Sri Listiyani:

“... saya dengan dinas sosial sudah berkoordiansi,
Disnaker dan Dinsos pernah satu kantor. Nomen-
klaturnya baru 2017. Jadi ini pernah Dinas sosial
dan Tenaga Kerja, Disnaker, Dinas Catatan Sipil
dan Tenaga Kerja juga pernah. Jadi selama otonomi
daerah itu, nomenklaturnya berubah-ubah. Sekarang
Dinas kami Dinas Tenaga Kerja, sosial sudah berdiri
sendiri. Jadi selama ini saya juga kalau mau ada pela-
tihan saya juga koordinasi dengan Dinas Sosial”. (Sri
Listiyani, Disnaker Kab. Semarang, 2018)

Permasalahan lain yang banyak disampaikan adalah program pemerintah yang terkesan top-down dan dilakukan sekadar untuk memenuhi serapan anggaran, sebagaimana disampaikan sebagai berikut:

"Kedua tentang BLK. Di sini dari dulu tidak berubah pola kerjanya, sekadar menghabiskan anggaran, hasilnya juga tidak bisa dipertanggungjawabkan menurut saya. Saya diminta mengajar di Lembaga bukan pemerintah untuk orang berkebutuhan khusus. Mengajar 20 non-difabel dibanding 5 difabel, lebih capek mengajar 5 orang difabel karena harus menyesuaikan masing2 sampai dimana kemampuan dan tingkat difabelnya di BLK pukul rata, tidak diperhatikan, tidak ada tindakan penyesuaian". (Ratna, PPDI Kabupaten Semarang, 2018)

Permasalahan-permasalahan tersebut cukup menghawatirkan mengingat pemerintah merupakan 
salah satu pihak yang bisa mengintervensi kemiskinan termasuk di antaranya dengan mendorong ketersediaan lapangan kerja. Wahyudi dan Rejekingsih (2013) melihat peran pemerintah untuk melakukan investasi publik sehingga mempengaruhi distribusi pendapatan, dan investasi sumber daya manusia yang mempengaruhi pertumbuhan ekonomi dan kemiskinan di Indonesia. Akibat belum optimalnya peran pemerintah dalam penyediaan lapangan kerja, maka beban pemuda untuk dapat mendapatkan pekerjaan menjadi lebih berat. Proses memasuki dunia kerja pemuda di Indonesia beralih pada modal sosial-ekonomi yang dimiliki masing-masing individu. Bagi pemuda yang tidak meneruskan jenjang pendidikan tinggi, salah satu pilihan adalah bekerja di pabrik sebagai buruh, menekuni bidang pertanian, dan sektor informal. Para informan memberikan keterangan sebagai berikut:

"Ya sekarang bantu bapak ibu di kebun sama ngurus sapi" (Ayah dari Maryanti, bisu-tuli, Kab. Boyolali, 2018)

“...iya keliling, terus saya lihat prospeknya lebih bagus jualan jagung saya ganti jualan jagung, kalau jualan jagung sya sudah 3 tahun lebih". (Ginarso, pedagang, tuna daksa, Kab. Semarang, 2018)

Masing-masing pilihan yang ada membawa pemuda pada risiko lain. Pekerja pabrik kebanyakan direkrut dengan sistem kontrak sehingga tidak menjanjikan jenjang karir. Sedangkan pertanian tidak menjanjikan pendapatan yang tetap dikarenakan harga komoditas yang fluktuatif dan menyempitnya lahan pertanian seiring bertambahnya jumlah penduduk. Pilihan lain yang bisa diambil oleh pemuda adalah wirausaha. Pada kenyataannya kebanyakan wirausaha hanya cukup untuk bertahan hidup atau subsisten.

Faktor lain yang mempengaruhi transisi pemuda memasuki dunia kerja di Jawa tengah adalah akses. Akses disini meliputi infrastruktur, pendidikan, informasi, kesehatan, dan lapangan pekerjaan. Permasalahan akses ini terutama sangat berpengaruh bagi pemuda difabel. Keadaan ini sesuai dengan keterangan yang diberikan oleh para informan sebagai berikut:

\footnotetext{
"Yanti nggak neruskan sekolah karena sudah bisa baca dan ngitung, pinter nggambar. Sekolah juga harus ke kota" (Kakak dari Maryanti, bisu-tuli, Kab. Boyolali, 2018)
}

\begin{abstract}
"Diajak kerja cuci motor, cuci mobil. Cuman kan harus ada yang bimbing kalau sendirian kan nggak mungkin. Komunikasi sama pelanggane kan susah." (Inung (tuna daksa) tentang Irham (tuna rungu), Kab. Semarang, 2018)
\end{abstract}

Ketersediaan akses mempermudah mobilitas warga, peredaran barang, peredaran informasi, dan pertumbuhan komunitas. Dalam konteks pemuda rentan di Jawa Tengah, komunitas/kelompok pemuda juga berfungsi sebagai hub bagi pemuda dalam masalah pekerjaan. Studi ini mengonfirmasi bahwa informasi pekerjaan bagi pemuda banyak didapat melalui word of mouth atau dari mulut ke mulut dengan sebagian variasi disampaikan melalui media sosial dalam grup-grup pertemanan atau pencarian kerja. Sebagaimana disampaikan oleh beberapa informan sebagai berikut:

\footnotetext{
“...kalau lewat sosial media kan itu gratis menginfokan. Misal kita dapat 10 orang, kita manfaatkan untuk mengajak teman-teman lainnya". (Wahyu Pancaraning, HRD Kab. Semarang, 2018)

“...kadang diajak ikut dagang teman. ada juga yg nyuruh ternak tapi ayam saja, kambing nggak punya tempat. untuk tambahan. kemarin waktu ternak ayam agak berantakan, ayam sering masuk rumah.... (Paidi, serabutan, Kab. Semarang, 2018)
}

Pemuda difabel di pedesaan seperti Kabupaten Boyolali dalam proses transisi akan bersandar pada keluarga yang secara kultural memiliki hubungan interdependensi yang kuat. Sedangkan di wilayah dekat perkotaan seperti Kabupaten Semarang keberadaan komunitas-komunitas difabel membantu pemuda difabel dalam melalui proses transisi memasuki dunia kerja. Komunitas berperan sebagai tempat bersosialisasi, mengembangkan diri, dan menyediakan akses pekerjaan yang sesuai. Selain itu akses yang terbatas bagi difabel di pedesaan menghambat mereka untuk bisa saling terkoneksi satu dengan lainnya. Sebagaimana disampaikan oleh beberapa informan berikut ini:

\footnotetext{
"Banyak yang laki-laki sama perempuan. Beda-beda, tapi ada yang laki-laki salah satu itu temen-temen jauh-jauh". (Ibu dari Ikhwan (tuna grahita) tentang pertemanan anaknya, Kab. Semarang, 2018)

"Iya aktif dia. Jane yo ingin pelatihan tapi yo pundi yang khusus [Sebenarnya ya ingin pelatihan yang mana yang khusus]. Kalau campur yang normal-normal kan... Dia kan yang khusus kan. Ya mboten
} 
enten informasi lak yo mboten ngertos [Ya tidak ada informasi ya tidak tahu]." (Ibu dari Ibnu (tuna grahita) tentang anaknya, Kab. Boyolali, 2018)

Dari pemaparan di atas terlihat bahwa komunitas dan keluarga menjadi jaring pengaman sosial bagi pemuda rentan dalam memasuki dunia kerja. Akses pekerjaan dan pemenuhan kebutuhan dasar yang tidak disediakan oleh pemerintah diambil alih penyediaannya oleh komunitas dan keluarga. Proses transisi pemuda di wilayah pedesaan memiliki dinamika yang berbeda dengan wilayah perkotaan. Perbedaan lingkungan sosial, budaya, ekonomi menyebabkan perbedaan tantangan dan kesempatan yang dimiliki oleh pemuda dari dua wilayah tersebut.

Konektivitas: Alternatif Perlindungan Sosial bagi Kaum Muda Urban

Adaptasi dalam transisi kepemudaan tidak lepas dari pengaruh lingkungan sekitar. Di sisi yang lain, kerentanan akibat keputusan memilih dan beradaptasi oleh pemuda tidak terlepas dari pengaruh pemerintah. Untuk memahami perhatian dan praktik pemerintah serta kemasyarakatan terkait pemuda, ada perlunya menerapkan pengertian "governmentalis" pada tata kelola pemuda (Nadesan dalam Naffs dan White 2012: 96). Melihat peluang peningkatan ekonomi dari bonus demografi, pemerintah Indonesia bermaksud memajukan ekonomi dengan mengoptimalisasi sumber daya yang ada. Tujuan utamanya masih sangat dasar yaitu peningkatan ekonomi secara merata. Arah kebijakan yang berkaitan dengan perlindungan sosial untuk kaum muda tidak ada yang tertulis secara eksplisit. Keseluruhan aturan hukum untuk mengarahkan aktivitas kaum muda diatur melalui UU No. 40 tahun 2009 tentang Kepemudaan. Beberapa kota besar seperti Pemerintah Daerah Kota Bogor memiliki sikap untuk menyusun Raperda (Rancangan Peraturan Daerah) Kepemudaan. Hal ini dilakukan untuk mendorong eksistensi pemuda serta Organisasi Kepemudaan (OKP) yang ada di Kota Bogor yang diklaim belum mengakomodir peran semua organisasi kepemudaan secara keseluruhan. (Kotabogor.go.id. 2017).

Dalam dokumen yang diterbitkan oleh BPS (2014), diterangkan bahwa program perlindungan sosial di Indonesia memegang peranan penting dalam upaya pengentasan kemiskinan serta pembangunan ekonomi. Diperlukan cara pandang yang berbeda terhadap sistem perlindungan sosial di Indonesia. Terdapat beberapa hal yang menjadi tantangan dalam pelaksanaan perlindungan sosial di Indonesia. Pertama, penargetan sasaran dalam implementasi program perlindungan sosial belum optimal. Kedua, mekanisme pendampingan program perlindungan sosial yang masih tergolong lemah. Ketiga, koordinasi antar-program secara terstandar dan terintegrasi belum terlaksana dengan baik. Keempat, prioritas pendanaan untuk program perlindungan sosial masih terbatas. Oleh sebab itu, upaya penguatan dalam sisi pendanaan, regulasi, dan kelembagaan diperlukan agar pelaksanaan perlindungan sosial menjadi lebih baik di masa depan (BPS 2014).

Namun dalam kenyataannya, program pembangunan masih terlihat urban sentris. Sebagai pembanding dengan kasus di Jawa Tengah, kehidupan kaum urban di wilayah DKI. Jakarta sebagai pusat sektor pembangunan dan pertumbuhan ekonomi memiliki keunikan tersendiri, salah satunya dalam menciptakan alternatif perlindungan sosial. Mereka membangun konektivitas yang menjadi wadah mengembangkan diri sekaligus memenuhi kebutuhan perlindungan sosial. Konektivitas dalam konteks ini adalah berbagai macam peran di dalam sebuah komunitas. Beberapa komunitas tersebut di antaranya adalah Komunitas Jendela Jakarta, Komunitas Organik Indonesia, Komunitas Indonesia Untuk Demokrasi, Bye Bye Plastic Bags Jakarta, Sahabat Anak Cijantung, Rumah Belajar Kita, dan sebagainya yang bergabung di www.mudazine.com. Dengan kata lain, dibandingkan di kota, masyarakat pedesaan minim akan adanya budaya baru termasuk di dalamnya adalah eksistensi beragam jenis komunitas.

Lebih lanjut, kaum muda di Jakarta berdasarkan karakter sosial dan ekonomi terdiri dari kelompok menengah atas dan kelompok menengah bawah. Masing-masing kelompok memiliki gaya perilaku yang berbeda mulai dari konektivitas jaringan sosial hingga pemilihan mode kendaraan untuk mobilitas. Dalam membangun jaringan sosial, kelompok kaum muda urban menengah atas melihat bagaimana peluang kreativitas dapat dimanfaatkan sebagai salah 
satu ranah untuk bertransformasi. Kaum muda menengah atas mempunyai banyak pilihan dibandingkan kelompok menengah bawah. Sebaliknya, studi ini menemukan bahwa ruang kreativitas di daerah perdesaan seperti Kabupaten Boyolali masih relatif rendah.

Berdasarkan data BPS (2017), jumlah penduduk usia 15-29 tahun mencapai 2.640.199 orang. Jumlah penduduk usia muda di Ibukota berasal dari berbagai daerah kemudian menetap di Jakarta. Mereka memerlukan perlindungan sosial informal untuk mencapai tingkat perkembangan fisik dan mental. Komunitas atau kelompok di kalangan pemuda di Jakarta menjadi salah satu pilihan terutama melalui medium online (internet). Berdasarkan penelitian yang dilakukan oleh Kominfo dan UNICEF (2014), data memperlihatkan setidaknya 30 juta anak-anak dan remaja di Indonesia merupakan pengguna internet, dan media digital menjadi pilihan utama komunikasi yang digunakan. Hasil studi menemukan bahwa $80 \%$ responden merupakan pengguna internet, dengan kesenjangan digital yang kuat antara mereka yang tinggal di wilayah perkotaan dan lebih sejahtera di Indonesia, dibandingkan mereka yang tinggal di daerah perdesaan dan kurang sejahtera. Di Yogyakarta, Jakarta, dan Banten, misalnya hampir semua responden merupakan pengguna internet. Sementara di Maluku Utara dan Papua Barat, kurang dari sepertiga jumlah responden telah menggunakan internet. Dari data tersebut, tentu konektivitas yang menjadi sumber perlindungan sosial secara informal di wilayah Maluku Utara dan Papua Barat menjadi tidak berjalan secepat di kota-kota besar.

Di Jakarta, akses internet untuk keberlangsungan eksistensi kaum muda sangat luas. Anak muda banyak memaksimalkan waktu dan kreatifitasnya untuk berkontribusi agar peer group-nya terjamin eksistensinya dalam waktu yang relatif lama. Ruang gerak kaum muda di perkotaan secara umum lebih beragam dibandingkan dengan wilayah perdesaan. Studi ini juga menunjukkan bahwa di daerah perkotaan hanya 13\% dari anak dan remaja yang tidak menggunakan internet, sementara daerah perdesaan sebesar $87 \%$. Hal ini menunjukkan gap yang signifikan dalam literasi digital. Hal ini berdampak pada bagaimana respon pemerintah untuk merangkul mereka dalam kebijakan yang sesuai dengan kondisi terkini mereka. Dalam proses selanjutnya diharapkan ada kebijakan untuk melindungi hak-hak anak mengakses informasi, berbagi informasi, dan mengekspresikan pandangan atau ide-ide mereka secara aman (KOMINFO 2014). Seperti yang dikemukakan oleh Menteri Kominfo, Rudiantara (2018), mengatakan, "Kita harus mendorong anak-anak dan remaja untuk menggunakan internet sebagai alat yang penting untuk membantu pendidikan, meningkatkan pengetahuan, dan memperluas kesempatan serta keberdayaan dalam meraih kualitas kehidupan yang lebih baik".

Walaupun terdapat data dari KOMINFO pada tahun 2018 tentang berbagai program pengiriman subsidi internet ke berbagai wilayah terluar, namun masih banyak pemuda di daerah yang belum menikmati akses tersebut. Hal ini merupakan potret realitas kesenjangan sosial di Indonesia karena di sisi lain DKI Jakarta menjadi ladang informasi dengan akses internet sangat merata serta menjadi salah satu trademark pusat pertumbuhan ekonomi.

\section{KESIMPULAN}

Dianggap sebagai suatu fase transisi, pemuda di satu sisi dipandang sebagai ancaman atas tatanan yang sudah ada, di sisi lain dianggap perlu dilindungi karena dianggap rawan terpengaruh hal-hal negatif yang dibawa oleh modernitas. Dalam konteks pemuda rentan di Jawa Tengah, ketidakoptimalan kebijakan perlindungan sosial menambah kerumitan permasalahan. Kebijakan perlindungan sosial yang seharusnya menjamin kebutuhan dasar seperti infrastruktur, pendidikan, kesehatan, dan pekerjaan tidak memadai sehingga pemuda tidak mendapat proteksi yang cukup dari risiko-risiko seperti putus sekolah, pengangguran, dan kemiskinan yang berkelanjutan. Kondisi ini mengharuskan pemuda mencari jalan keluar tanpa banyak mengharapkan campur tangan pemerintah. Pemuda dipaksa berhadapan dengan pasar dan korporasi dengan mengandalkan diri mereka sendiri, sehingga tidak memiliki banyak ruang untuk bernegosiasi. Ketiadaan ruang negosiasi ini menghilangkan kesempatan pemuda yang bekerja di sektor 
industri untuk mendapatkan kompensasi yang layak atas pekerjaan yang dijalaninya, kondisi ini semakin buruk bagi pemuda difabel dimana hanya sedikit perusahaan yang mau mempekerjakan mereka. Pemuda yang tidak bisa memenuhi tuntutan persyaratan untuk masuk ke industri akan mencari jalan lain seperti wirausaha, namun sebagian besar di antaranya adalah untuk sekedar bertahan hidup. Di sisi yang lain, pemuda bergantung pada jaringan sosial informal dimana dalam kenyataannya kapasitas antara pemuda perkotaan dan pedesaan sebagaimana dicontohkan pada kasus Jakarta dan Jawa Tengah dalam membangun konektivitas berbasis digital masih cenderung timpang.

Pangkal dari permasalahan ini adalah tidak optimalnya peran pemerintah sebagai penyedia perlindungan sosial dan sekaligus regulator dalam dunia ketenagakerjaan. Hal ini berakibat berpindahnya beban risiko kepada pemuda sebagai individu sehingga pemuda harus mengembangkan cara mempertahankan kehidupan dengan cara masing-masing sesuai dengan modal dan kapasitas yang dimiliki (Sutopo dan Meiji 2017). Keadaan ini dalam jangka panjang akan menjadi permasalahan yang besar mengingat Indonesia akan mengalami puncak bonus demografi pada dekade mendatang yang bila tidak terkelola dengan baik justru akan menjadi beban nasional.

\section{DAFTAR PUSTAKA}

Abidi, Javed dan Dorodi Sharma. 2014. "Poverty, Disability, and Employment: Global Perspectives from the National Centre for Promotion of employment for Disabled People." Career Development and Transition for Exceptional Individuals 2014, Vol. 37(1) 60-68

Agenda Pembangunan Nasional Rencana Pem bangunan Jangka Menengah Nasional 2015 2019.

Amiluddin. 2018. "Perlindungan Sosial Anak Usia Sekolah Melalui Program Keluarga Harapan di Desa Mangepong Kecamatan Turatea Kabupaten Jeneponto." Skripsi. Jurusan PMI Fakultas Dakwah dan Komunikasi UIN Alauddin Makassar.
Badan Pusat Statistik. 2014. "Statistik Pemuda Indonesia 2014". Diakses pada 20 Agustus 2018 (https://www.bps.go.id/publication/ 2015/11/02/f4bbb65bbc11ad61a75695b3/ statistik-pemuda-indonesia-2014.html)

Badan Pusat Statistik. 2016. "Profil Ketenagakerjaan di Indonesia." Diakses pada 20 Agustus 2018 (https://www.bps.go.id/subject/6/ tenaga-kerja.html)

Badan Pusat Statistik. 2017. "Survei Angkatan Kerja Nasional." Diakses pada 21 Agustus 2018 (https://microdata.bps.go.id/mikrodata/ index.php/catalog/SAKERNAS)

Badan Pusat Statistik. 2018. "Statistik Pemuda Indonesia 2018". Diakses pada 21 Agustus 2018 (https://www.bps.go.id/publication/2018 /12/21/572f941511d090083dd7 42d6/statistik-pemuda-indonesia-2018.html)

Carmona, Magdalena Sepulveda dan Olivier De Schutter. 2012. Report of the Special Rapporteur on Extreme Poverty and Human Rights. Diakses pada 20 Agustus 2018 (https:// papers.ssrn.com/sol3/papers.cfm?abstract_ id $=2534341$ )

France, Alan. 2007. Understanding Youth in Late Modernity. NY, USA: McGraw-Hill.

Kertati, Indra. 2013. "Analisis Kemiskinan Kota Semarang berdasarkan Data Pendataan Program Perlindungan Sosial (PPLS)”. Jurnal Riptek Vol. 7 No.1. Hal. 27-38.

Kiling, Indra Yohanes, Clemence Due, Dominggus Elcid Li dan Deborah Turnbull. 2018. "Interventions Supporting Development of Young Children with Disabilities at Environtmental Risk in Indonesia: A Scoping Review." SAGE Open January-March 2018: 1-9.

Marvasti, Amir B. 2003. Qualitative Research in Sociology. New York: SAGE Publishing

Minza, Wenty Marina. 2014. Masa Muda Sebagai Masa Transisi. dalam M. Najib Azca, Derajad S. Widhyharto dan Oki Rahadianto Sutopo (Ed). Buku Panduan Studi Kepemudaan. Yogyakarta: Youth Studies Centre (YouSure) Universitas Gadjah Mada. 
Naffs, Suzanna dan White, Ben. 2012. "Generasi Antara: Refleksi Tentang Studi Pemuda Indonesia." Jurnal Studi Kepemudaan Vol.1 No. 2. Hal.89-106

Norton, Andy, Tim Conway dan Mick Foster. 2001. Social Protection Concepts and Approaches: Implications for Policy and Practice in International Development. London: Overseas Develompment Institute.

Strategic Alliance for Poverty Alleviation (SAPA). 2018. "Perlindungan Sosial dan Pemenuhan Hak Dasar." Diakses 22 Oktober 2018 ( http:// www.sapa.or.id/perlindungan-sosial-dan-pemenuhan-hak-dasar ).

Suharto, Edi. 2009. Kemiskinan dan Perlindungan Sosial di Indonesia: Mengagas Model Jaminan Sosial Universal Bidang Kesehatan. Bandung: Alfabeta.

Sutopo, Oki Rahadianto. 2014. Perspektif Generasi dalam Kajian Kepemudaan. dalam M. Najib Azca, Derajad S. Widhyharto dan Oki Rahadianto Sutopo (Ed). Buku Panduan Studi Kepemudaan. Yogyakarta: Youth Studies Centre (YouSure) Universitas Gadjah Mada.

Sutopo, Oki Rahadianto dan Nanda Harda Pratama Meiji. 2017. "Kapasitas Refleksif Pemuda dalam Transisi Menuju Dunia Kerja." Jurnal Sosiologi Walisongo. Hal 1-15.

Sutopo, Oki Rahadianto dan Wenty Marina Minza. 2014. Perspektif Budaya dalam Kajian Kepemudaan: Identitas Sosial dan Subkultur Pemuda. dalam M. Najib Azca, Derajad S. Widhyharto dan Oki Rahadianto Sutopo (Ed). Buku Panduan Studi Kepemudaan. Yogyakarta: Youth Studies Centre (YouSure) Universitas Gadjah Mada.

Taqwa, Zaadit. 2018. "Anak dan Ibu Suku Asmat Adalah Kita”. Diakses 22 Oktober 2018 ( https://kitabisa.com/donasiasmat ).

United Nations. 2012. Social protection: A Development Priority in the Post-2015 UNDevelopment Agenda. Report. Diunduh pada 20 Agustus
2018 (http://www.un.org/millenniumgoals/pdf/ Think\%20Pieces/16_social_protection.pdf)

United Nations. 2018. Social Protection and the Global Compact on Refugees. Geneva: United Nations.

UU No. 40 tahun 2009 Tentang Kepemudaan.

UU No. 8 Tahun 2016 Tentang Penyandang Disabilitas.

UU No.11 Tahun 2009 Tentang Kesejahteraan Sosial

Wahyudi, Dicky dan Rejekingsih. 2013. "Analisis Kemiskinan di Jawa Tengah." Diponegoro Journal of Economics 2(1):1-15.

Women in Informal Employment: Globalizing and Organizing (WIEGO). 2018. "Pillars of Social Protection”. Diakses 22 Oktober 2018 ( http:// www.wiego.org/pillars-social-protection ).

"Gempa dan Tsunami Palu: Bantuan Internasional Berdatangan, Tapi Mengapa Bantuan Medit Tak Difasilitasi?”. 2018. BBC Indonesia. Diakses 22 November 2018 ( https://www.bbc. com/indonesia/indonesia-45717773).

"Tawuran Pelajar Bukti Kegagalan Kebijakan Pemerintah. 2012. Kompas.com. Diakses pada 20 Agustus 2018. (https://megapolitan.kompas.com $/ \mathrm{read} / 2012 / 09 / 28 / 13202569 /$ Tawuran.Pelajar..Bukti.Kegagalan.Kebijakan.Pemerintah)

"Milenial Terancam Jadi Gelandangan di 2020". 2017. DetikFinance. Diakses pada19 Agustus 2018 (https://finance.detik.com/properti/d-3744907/95-kaum-milenial t e $\mathrm{r}$ a $\mathrm{n}$ cam-jadi-gelandangan-di-2020)

"Bahaya Glorifikasi Generasi Milenial Malam”. 2018. Kompas. (https://lifestyle.kompas.com/ $\mathrm{read} / 2018 / 08 / 23 / 073100420 /$ bahaya-glorifikasi-generasi-milenialmalem)

"DPRD Bahas Raperda Pelayanan Kepemudaan". 2017. Kabar Online. Diakses pada 20 Agustus 2018 (http://kabaronline.co.id/20817-2/) 
"Penduduk Indonesia" Indonesia Investment. Diakses pada 23 Austus 2018. (https://www.indonesia-investments.com/id/budaya/penduduk/ item67

"10 Tempat Nongkrong di Jakarta Selatan Bikin Betah 24 Jam Rekomended”. 2018. Gotravelly. Diakses pada 20 Agustus 2018 (https://www. gotravelly.com/blog/tempatnongkrong-di-jakarta-selatan)

"Riset Kominfo dan UNICEF Mengenai Perilaku Anak dan Remaja dalam Menggunakan Internet”. 2014. KOMINFO. Diakses pada 20 Juni
2018. (https://kominfo.go.id/content/detail/ 3834/siaran-pers-no-17pihkominfo22014-tentang-riset-kominfo-dan-unicef-mengenai-perilaku-anak-dan-remaja-dalam-menggunakan-internet/0/siaran_pers)

"KNPI Kota Bogor Dorong Pengesahan Raperda Kepemudaan”. 2017. Diakses pada 21 Juni 2018 (https://kotabogor.go.id/index.php/show post/detail/7123/KN PI - Kota-Bogor-Dorong-Pengesahan-Raperda-Kepemudaan) 